\title{
Influence of Microstructure on Mechanical Properties of Bainitic Steels in Railway Applications
}

\author{
Omid Hajizad ${ }^{1}$, Ankit Kumar ${ }^{2}$, Zili Li ${ }^{1, * \mathbb{C}}$, Roumen H. Petrov ${ }^{2,3} \mathbb{D}^{\text {, Jilt Sietsma }}{ }^{2,3}$ \\ and Rolf Dollevoet ${ }^{1}$ \\ 1 Section of Railway Engineering, Faculty of Civil Engineering and Geoscience, Delft University of Technology, \\ 2628 CD Delft, The Netherlands \\ 2 Department of Materials Science and Engineering, Delft University of Technology, \\ 2628 CD Delft, The Netherlands \\ 3 Department of Electrical Energy, Metals, Mechanical constructions \& Systems, Ghent University, \\ B-9052 Ghent, Belgium \\ * Correspondence: Z.Li@tudelft.nl; Tel.: +31-152782325
}

Received: 3 June 2019; Accepted: 29 June 2019; Published: 11 July 2019

check for updates

\begin{abstract}
Wheel-rail contact creates high stresses in both rails and wheels, which can lead to different damage, such as plastic deformation, wear and rolling contact fatigue (RCF). It is important to use high-quality steels that are resistant to these damages. Mechanical properties and failure of steels are determined by various microstructural features, such as grain size, phase fraction, as well as spatial distribution and morphology of these phases in the microstructure. To quantify the mechanical behavior of bainitic rail steels, uniaxial tensile experiments and hardness measurements were performed. In order to characterize the influence of microstructure on the mechanical behavior, various microscopy techniques, such as light optical microscopy (LOM), scanning electron microscopy (SEM) and electron backscatter diffraction (EBSD), were used. Three bainitic grades industrially known as B360, B1400 plus and Cr-Bainitic together with commonly used R350HT pearlitic grade were studied. Influence of isothermal bainitic heat treatment on the microstructure and mechanical properties of the bainitic grades was investigated and compared with B360, B1400 plus, Cr-Bainitic and $\mathrm{R} 350 \mathrm{HT}$ in as-received (AR) condition from the industry. The results show that the carbide-free bainitic steel (B360) after an isothermal heat treatment offers the best mechanical performance among these steels due to a very fine, carbide-free bainitic microstructure consisting of bainitic ferrite and retained austenite laths.
\end{abstract}

Keywords: bainitic steel; pearlitic steel; isothermal heat treatment; microstructure; mechanical properties

\section{Introduction}

Energy and material conservation have stimulated research to produce high performance steels for structural applications. These steels should combine high strength with good ductility and toughness. Steels are widely used in railway infrastructure, and their good performance is crucial to enhance the safety of the system and to reduce the cost of repairs or replacements. There are multiple track components, such as straight tracks, curved tracks, switches and crossings (S\&Cs), that are manufactured from different steels and are subjected to various loading conditions. For example, rails suffer from high contact loads of frictional rolling, which create a complex multiaxial shear and compressive stress state. These high contact stresses eventually lead to rolling contact fatigue (RCF). The two major types of RCF defects are head checks (HC) and squats [1-6]. On the other hand, S\&Cs that help guide the trains from one track to another are subjected to rather complex loading conditions 
in comparison with the rails. At crossing, the wheel rolls from the wing rail to the crossing nose (also called frog) or in the opposite direction, generating heavy impact loads in addition to RCF and wear. These loading conditions deteriorate the crossing nose over time by local plastic deformation, irregular wear and various RCF defects. These defects can finally lead to failure if they are not repaired in time and would cause safety issues and financial costs due to replacement. Therefore, the steel used to manufacture S\&Cs must have good impact fracture toughness.

The response of the material to the forces acting in the contact zone between rail and wheel is of crucial importance. Due to these forces, rails (and wheels) will be deformed, and their properties will change over time. Mechanical properties such as yield and ultimate strength, uniform elongation, fracture toughness, hardness, impact strength and crack growth parameters provide valuable information about the way materials interact and fail under these external loadings. Some of these properties, such as yield and ultimate strength, uniform strain, true and engineering fracture strain, toughness, strain hardening exponent and hardness, are evaluated in this paper.

The mechanical behavior and damage in steels are directly dependent on their microstructure, and the key to producing steels with better mechanical properties lies in optimization of their microstructure. Most rails are made of steels with pearlitic microstructure, which is an alternating lamellar structure of ferrite and cementite. The mechanical behavior of different pearlitic rail steels in relation with their microstructure has been widely investigated in the literature [7-20]. The pearlitic rail steel grades offer appreciable wear resistance due to their hardness values ranging from 260 to $400 \mathrm{HB}$ [21]. The hardness values can be further increased by increasing the carbon content in pearlitic grades, which results in higher wear resistance in the steel microstructure [7], but this comes with the cost of reducing fracture toughness and producing poor weldability. The wear resistance of the pearlite steels can be further improved by refining the microstructure $[13,14]$ using accelerated cooling or by using high concentrations of $\mathrm{Mn}, \mathrm{Cr}, \mathrm{V}, \mathrm{Si}$ and $\mathrm{Mo}$ in the alloy composition [15-17,19]. Increased concentrations of these alloying elements shift the continuous cooling transformation curve towards longer times (decrease the critical quench rate), and fine pearlitic microstructure can be achieved with low cooling rates [20]. Some pearlitic steels, such as R350HT, which have good impact properties, are used to manufacture S\&Cs.

Cast manganese austenitic Hadfield steels are also used for this purpose due to their good work-hardening rate, high toughness and excellent wear resistance properties under compressive loading [22,23]. These steels have low yield strength, which can cause excessive deformation and consequently work hardening, which leads to change in the geometry of the crossing. In this case, welding is used to restore the original dimensions of the crossing. However, Hadfield steels have poor weldability, which is usually due to high carbon content and formation of carbides during the cooling process after welding, which can decrease the material toughness [24]. Furthermore, higher thermal expansion coefficient of Hadfield steel compared to pearlitic grades can cause problems during welding [25,26].

Due to high speed and high axle load requirements of future railways, new steel grades are required. Bainitic steels are a good candidate because of their excellent mechanical properties, such as high strength and toughness. This microstructure was discovered by Bain and Davenport [27] and generally forms by phase transformation in the temperature range between pearlite finish and martensite start temperatures. Depending on the bainite transformation temperature, there exist two distinct forms of bainite, i.e., upper bainite and lower bainite. The upper bainite, which is obtained in the high temperature range $\left(\sim 400-500{ }^{\circ} \mathrm{C}\right.$ for the rail steels), consists of coarser laths of bainitic ferrite and carbides than lower bainite formed in the lower temperature range $\left(300-400{ }^{\circ} \mathrm{C}\right)$ [26-31]. This results in poorer mechanical properties in the upper bainite [32,33] than in the lower bainite, which offers better mechanical properties, namely strength, hardness and toughness [33-35]. The bainitic steels primarily contain lamellar structures of bainitic ferrite and cementite. The brittle cementite phase is considered to be detrimental for the fatigue properties of the bainitic steels [35]. The precipitation of cementite can be suppressed by using high concentration of Si and Al, which leads to the formation 
of carbide-free bainitic microstructures. This microstructure consists of bainitic ferrite and retained austenite lamellae, and due to high strength, ductility and toughness, it is being used extensively in industry [36-39]. Bainitic rails can be produced with conventional methods by natural air cooling after rolling. They have hardness above $400 \mathrm{HB}$ and fracture toughness much better than the conventional head-hardened $(\mathrm{HH})$ pearlitic rail steels. This results in much better RCF resistance together with a wear resistance at least as good as in $\mathrm{HH}$ pearlitic rail steels [40]. It was also reported that for most laboratory rolling/sliding tests, with the same hardness, bainitic microstructures are more wear resistant than pearlitic ones [41].

The microstructure of the steels is dependent on their chemical composition and the heat treatment performed on them during production process. The variations in the bainitic-type microstructures can be very large and depend significantly on the chemical compositions and the thermal treatment parameters, such as austenitization temperature/time, bainitic isothermal temperature/time and cooling rates. These variations in microstructures during bainitic transformation are also sensitive and dependent on the dimensions of the rails. That is why the bainitic microstructures in rails can often contain lower, upper bainite, martensite and retained austenite. Having in mind the growing interest of the rail industry for the bainitic steels, this work aims to compare the influence of bainitic microstructures formed in different bainitic rail steels on their mechanical properties. The intention of the work is to focus on the mechanical properties in relation to the microstructure but not on the specific details of the formation of the microstructures. Including also these aspects would make the study too extensive. That is why the microstructures of the rail steels are described qualitatively and quantitatively, but the specific physical metallurgy aspects of bainite formation are not discussed.

These bainitic grades in as-received (AR) condition and after the heat treatment (HT) were compared using uniaxial tensile tests and hardness measurements. In this way, we can understand the influence of the specific microstructures on the mechanical performance of these bainitic steels. The performance of these bainitic steels is also compared with commonly used R350HT pearlitic grade. The mechanical properties, such as maximum tensile strength, yield strength, uniform elongation, engineering and true fracture strains, toughness and strain hardening exponent (SHE) were obtained from tensile testing. Hardness of the steels was also compared using micro-hardness measurements. In order to investigate the influence of microstructure on these properties, imaging techniques such as light optical microscopy (LOM), scanning electron microscopy (SEM) and electron backscatter diffraction (EBSD) were used. At the end, as conclusion, the most suitable combination of steel grade and heat treatment is proposed for a more sustainable railway network.

\section{Material and Experimental Methods}

\subsection{Chemical Composition, Sampling and Material Processing}

The chemical composition of the steels studied in this paper is shown in Table 1. The bainitic steels have less carbon compared to the pearlitic grade. B360 has the lowest carbon content $(\approx 0.27 \mathrm{wt} \%)$ and a high concentration of Si. Both bainite 1400 (B1400) and chrome bainitic (CrB) steels grades have equal carbon content $(\approx 0.36 \mathrm{wt} \%)$ with different concentrations of other alloying elements.

Table 1. Chemical composition of steels in (wt \%).

\begin{tabular}{ccccccccccccc}
\hline $\begin{array}{c}\text { Steel } \\
\text { Grade }\end{array}$ & $\mathbf{C}$ & $\mathbf{C r}$ & $\mathbf{M n}$ & $\mathbf{S i}$ & $\mathbf{V}$ & $\mathbf{M o}$ & $\mathbf{S}$ & $\mathbf{C u}$ & $\mathbf{A l}$ & $\mathbf{P}$ & $\mathbf{N i}$ & $\mathbf{N}$ \\
\hline B360 & 0.269 & 0.51 & 1.547 & 1.36 & 0.033 & 0.148 & - & - & - & - & - & 0.006 \\
B1400 & 0.363 & 1.146 & 0.934 & 0.694 & 0.095 & 0.713 & 0.0009 & 0.242 & - & - & 0.223 & 0.008 \\
CrB & 0.367 & 2.722 & 0.726 & 0.595 & 0.109 & 0.3 & 0.0008 & 0.05 & 0.0069 & 0.0059 & 0.059 & 0.009 \\
R350HT & 0.72 & 0.11 & 1.1 & 0.5 & - & - & - & - & 0.004 & 0.02 & - & - \\
\hline
\end{tabular}

The different bainitic steel grades, including B360, B1400, chrome bainitic (CrB) in as-received (AR) and heat-treated (HT) conditions and pearlitic R350HT steel, were compared for their mechanical 
performance under uniaxial tensile experiments. The samples were cut and prepared using electron discharge machining (Makino, Tokyo, Japan) in combination with turning and polishing on lathe machine from the real rail specimens (as shown in Figure 1).

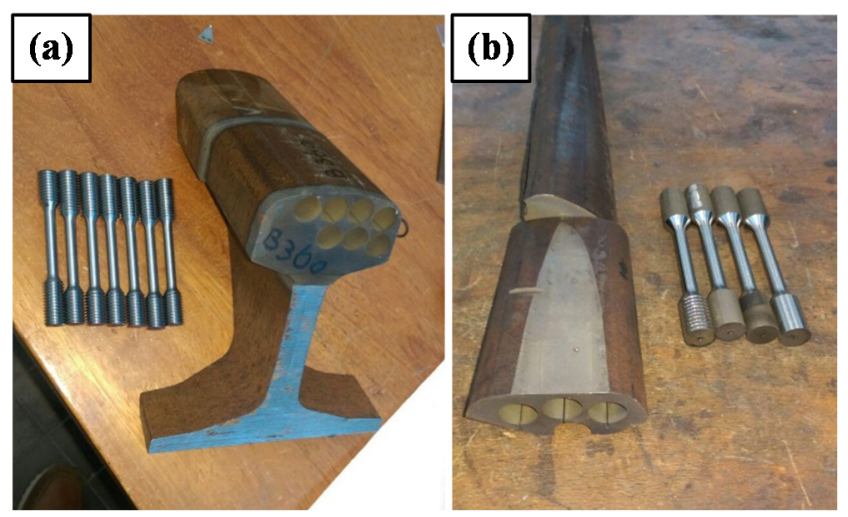

Figure 1. Sample preparation for uniaxial tensile test machine; $(\mathbf{a}, \mathbf{b})$ Images of specimens cut from real used rails.

For each grade, samples with the geometry shown in Figure 2 and with dimensions presented in Table 2 were cut and prepared. Heat treatment was performed on these samples. The uniaxial tensile test in each condition was performed on at least three samples to make sure that the results were reliable and representative.

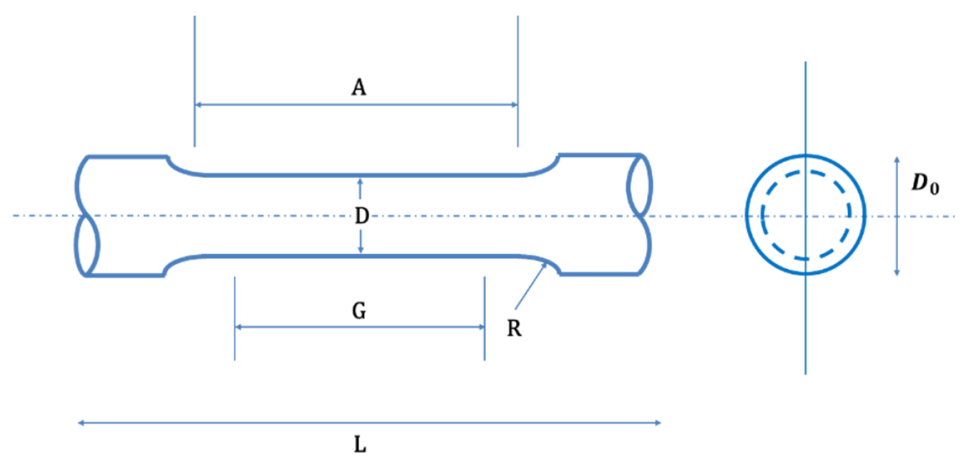

Figure 2. Tensile sample dimensions.

Table 2. Tensile sample dimension.

\begin{tabular}{cc}
\hline G (Gauge length) & $30.0 \pm 0.1 \mathrm{~mm}$ \\
D (Diameter) & $6.0 \pm 0.1 \mathrm{~mm}$ \\
$\mathrm{R}$ (Minimum radius of fillet) & $6 \mathrm{~mm}$ \\
A (Minimum length of reduced section) & $36 \mathrm{~mm}$ \\
L (Full specimen length) & $85 \pm 5 \mathrm{~mm}$ \\
$\mathrm{D}_{\mathrm{o}}$ (Diameter of the gripping section) & $\geq 12 \mathrm{~mm}$ \\
\hline
\end{tabular}

In as-received condition, B360-AR and CrB-AR steel grades were produced by austenitization followed by continuous cooling to room temperature, while B1400-AR grade is isothermally heat treated with a hold at $400{ }^{\circ} \mathrm{C}$ for $30 \mathrm{~min}$. To optimize both strength and toughness of the steels, the isothermal heat treatment shown in Figure 3 was used for the bainitic grades. The heat-treatment process involves first heating the samples up to $900^{\circ} \mathrm{C}$ and keeping them there for $10 \mathrm{~min}(600 \mathrm{~s})$. Afterwards, specimens were brought to $330^{\circ} \mathrm{C}$ to be austempered for $60 \mathrm{~min}$ (3600 s) and subsequently oil quenched to room temperature. 


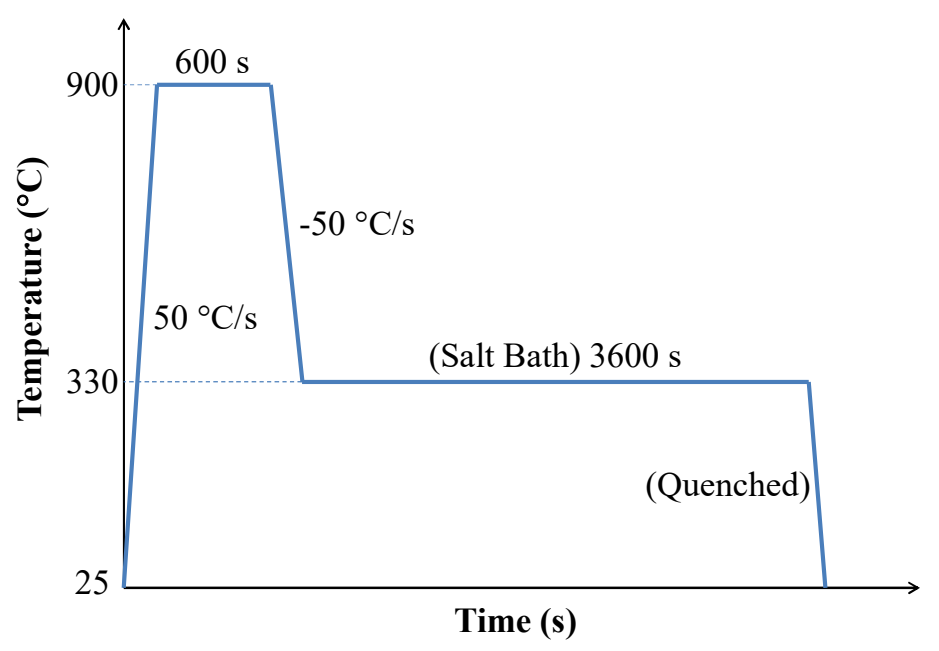

Figure 3. Scheme of the planned heat-treatment process.

\subsection{Uniaxial Tensile Testing}

Uniaxial tensile tests were performed at the room temperature on an INSTRON 2200 machine with a constant cross head speed of $1 \mathrm{~mm} / \mathrm{min}$. The strain values were measured using a knife edge extensometer (INSTRON, Boechout, Belgium) with a gauge dimension of $12.5 \mathrm{~mm}$. The stress-strain diagrams for each steel were plotted. The mechanical properties such as yield strength, ultimate tensile strength, uniform elongation, engineering fracture strain, toughness and strain hardening exponent (SHE) were calculated from the resulting stress-strain diagram. The value of yield strength was taken at $0.2 \%$ engineering strain. The broken samples were further investigated for the fracture surface analysis on a Keyence VHX-5000 optical microscope (Keyence, Mechelen, Belgium). Reduction of area and true fracture strain, which are good measures for ductility, were measured using the fracture surface analysis.

\subsection{Hardness Measurement}

Hardness measurements were performed on a DuraScan 70 Vickers micro hardness tester (EMCO-TEST, Kuchl, Austria) under a load of $0.1 \mathrm{kgf}$ on different steel grades. The measurement results are shown in Section 3.4.

\subsection{Microstructural Characterization}

The specimens from the bainitic steels were prepared for metallographic observation using conventional grinding followed by polishing using the diamond paste, having particle size of 3 and $1 \mu \mathrm{m}$, respectively. Afterwards, the specimens were etched using 2 vol \% solution of nitric acid in ethanol ( $2 \%$ Nital) to reveal the microstructure under the light optical microscopy (LOM) and scanning electron microscopy (SEM). For LOM, a Keyence VHX-5000 (Keyence, Mechelen, Belgium) was used. The SEM imaging was conducted on a JEOL JSM-IT100 microscope (JEOL Ltd., Tokyo, Japan) with a tungsten filament. The imaging was conducted with an accelerating voltage of $30 \mathrm{kV}$ and working distance of $10 \mathrm{~mm}$. The EBSD characterization was performed using a FEI Quanta-450 SEM (FEI Company, Hillsboro, OR, USA) equipped with a field emission gun (FEG). A Hikari-Pro EBSD detector in combination with EDAX-TSL OIM Data Collection v.6.2 software (AMETEK BV, Tilburg, the Netherlands) was used for EBSD data collection. The EBSD measurements were performed with an accelerating voltage of $15 \mathrm{kV}$ with a step size of $50 \mathrm{~nm}$. The hexagonal scan grid mode was used for EBSD data collection. The EBSD data were further analyzed using a TSL OIM v. 7.0 software (AMETEK BV, Tilburg, the Netherlands) and phase fractions and grain sizes were determined. All points having a confidence index less than 0.1 were excluded from quantification during this analysis. 


\section{Results and Discussion}

\subsection{Tensile Tests}

The results of the tensile tests are presented in Figure 4 and Table 3. All the stress-strain curves are illustrated in Figure $4 \mathrm{a}$. Figure $4 \mathrm{~b}$ shows the comparison of the engineering uniform and fracture strain of these steels. Among the bainitic steels in as-received condition, B360-AR has the highest engineering fracture strain $(19.9 \pm 0.9 \%)$. The uniform strain is the strain up to maximum load and it is usually used to describe the formability of metals. B360-AR has also the highest uniform strain $(16.6 \pm 0.8 \%)$.

During necking, the cross section of the samples changes, so true fracture strain is used to accurately define the straining of ductile materials by considering the actual cross-section area after fracture. The true fracture strain is calculated using the reduction of area in the tensile specimens. Reduction of area is an important material characteristic that indicates the ductility of the material. Reduction of area $(\Delta A)$ and true fracture strain $\left(\varepsilon_{f}\right)$ are calculated by:

$$
\begin{gathered}
\Delta A=\frac{A_{0}-A_{\text {min }}}{A_{0}} \\
\varepsilon_{f}=\ln \frac{A_{0}}{A_{\text {min }}}=\ln \frac{1}{1-\Delta A}
\end{gathered}
$$

where $A_{0}$ is the area of original cross section and $A_{\text {min }}$ is the minimum final cross section after fracture.

It is observed in Figure 4c that all bainitic steels also show a higher true fracture strain than the R350HT pearlitic grade. Comparing bainitic grades in as-received condition, B1400-AR had the highest true fracture strain $(99.4 \pm 3.1 \%)$. The reason for the large difference in ductility (for as-received samples) is due to the isothermal heat treatment done on this rail steel (in industry) in contrast to the continuous cooling heat treatment that was performed on B360-AR and CrB-AR, which is explained more in Section 3.5. The isothermal heat treatment on bainitic steels increases the true fracture strain and hence increases the ductility. We observed that the true fracture strains of all bainitic steels are improved by the isothermal bainitic heat treatment. The true fracture strain of B1400-HT reaches to a value of around $167.1 \pm 2.2 \%$. However, the B360-HT steels show a true fracture strain of $171.4 \pm$ $2.7 \%$ which is the highest among all steels.

Figure $4 \mathrm{~d}$ shows the comparison of yield and ultimate tensile strength of all rail steels. All bainitic steels have higher yield and ultimate strength than the pearlitic R350HT steel. It is also observed that the yield and ultimate strength of all bainitic steels increase after the isothermal bainitic heat treatment. B360 has the highest increase compared to other steels, which results in B360-HT having the highest yield and ultimate strength of $1324 \pm 17$ and $1879 \pm 19 \mathrm{MPa}$, respectively. This is due to its fine carbide-free bainitic structure, which is explained in Section 3.5. Among all as-received bainitic grades, B1400-AR shows the highest yield strength. This can be due to the isothermal bainitic heat treatment of B1400-AR at $400{ }^{\circ} \mathrm{C}$ (in industry) in contrast to other as-received bainitic grades, which were produced by continuous cooling of samples to the room temperature. CrB-AR has the highest ultimate strength compared to other two as-received bainitic steels.

Figure 4e shows the comparison of toughness of all steel grades. Toughness is the capacity of the material to absorb energy by elastic and plastic deformation. Toughness is measured as the area under the stress-strain curve. B360-AR shows the highest toughness among all steels. Heat treatment does not seem to increase the toughness of steels, and just CrB-HT has higher toughness than its as-received form. The reason is that heat treatment increases the strength of these steels, and this causes them to fracture in a lower engineering strain value compared to as-received situation.

\subsection{Strain Hardening Exponent}

The strain hardening exponent measures the ability of a material to strain harden. Larger magnitudes indicate higher rate of strain hardening. This exponent was measured for all steels using 
Hollomon's model [42]. The true stress-strain curve of the steels during the uniform plastic deformation can be approximated as a simple power curve relation:

$$
\sigma_{t}=K \cdot \varepsilon_{t}^{n}
$$

where $\sigma_{t}$ is the true stress, $\varepsilon_{t}$ is the true strain, $n$ is the SHE and $K$ is the strength coefficient.

A log-log plot of this curve would result in a straight line. The slope of this line is calculated as strain hardening exponent (SHE).

Figure $4 \mathrm{f}$ shows the comparison of the measured SHEs for all steels. Pearlitic R350HT grade has the highest SHE $(0.24 \pm 0.005)$, while B1400-AR shows the lowest value for SHE. The exact values can be seen in Table 3.
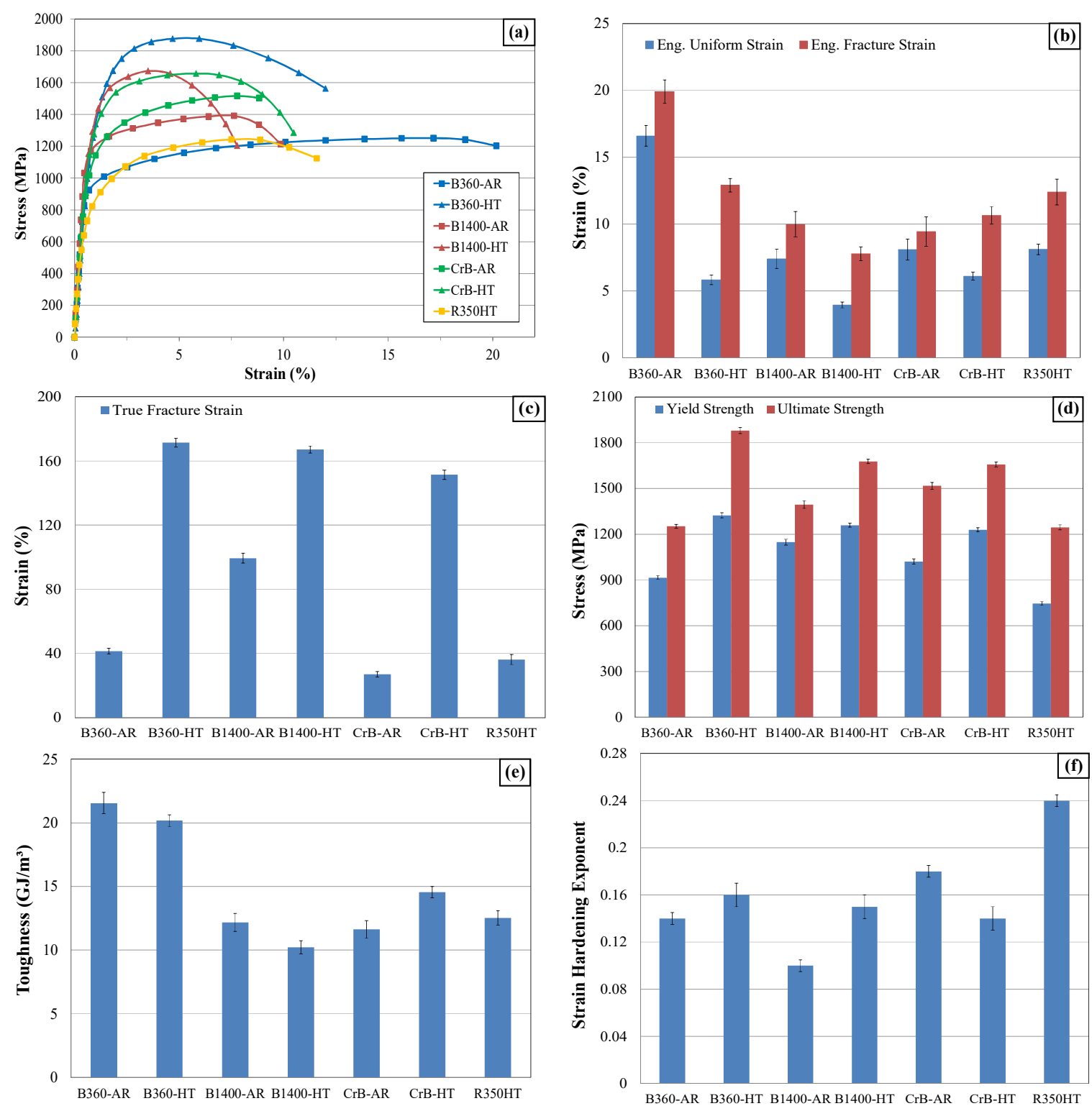

Figure 4. Comparison of mechanical properties of steels using results of the uniaxial tensile tests; (a) engineering stress-strain curves, (b) engineering uniform strain, engineering fracture strain, (c) true fracture strain, (d) yield and ultimate strength, (e) toughness and (f) strain hardening exponent (SHE). 
Table 3. The values of mechanical (tensile) properties for each steel.

\begin{tabular}{ccccccccc}
\hline Steels & $\begin{array}{c}\text { Eng. } \\
\text { Fracture } \\
\text { Strain (\%) }\end{array}$ & $\begin{array}{c}\text { Eng. } \\
\text { Uniform } \\
\text { Strain (\%) }\end{array}$ & $\begin{array}{c}\text { True } \\
\text { Fracture } \\
\text { Strain (\%) }\end{array}$ & $\begin{array}{c}\text { Yield } \\
\text { Strength } \\
\mathbf{( M P a )}\end{array}$ & $\begin{array}{c}\text { Ultimate } \\
\text { Strength } \\
\mathbf{( M P a )}\end{array}$ & $\begin{array}{c}\text { Toughness } \\
\left(\mathbf{G J} / \mathbf{m}^{\mathbf{3}}\right)\end{array}$ & SHE (-) & $\begin{array}{c}\text { Hardness } \\
(\mathbf{H V 0 . 1 )}\end{array}$ \\
\hline B360-AR & $19.9 \pm 0.9$ & $16.6 \pm 0.8$ & $41.5 \pm 1.8$ & $915 \pm 12$ & $1251 \pm 13$ & $21.5 \pm 0.8$ & $0.14 \pm 0.005$ & $380 \pm 8$ \\
\hline B360-HT & $12.9 \pm 0.5$ & $5.8 \pm 0.4$ & $171.4 \pm 2.7$ & $1324 \pm 17$ & $1879 \pm 19$ & $20.2 \pm 0.4$ & $0.16 \pm 0.01$ & $545 \pm 9$ \\
\hline B1400-AR & $9.98 \pm 0.9$ & $7.4 \pm 0.7$ & $99.4 \pm 3.1$ & $1147 \pm 19$ & $1394 \pm 25$ & $12.2 \pm 0.7$ & $0.10 \pm 0.005$ & $510 \pm 15$ \\
\hline B1400-HT & $7.77 \pm 0.5$ & $3.9 \pm 0.2$ & $167.1 \pm 2.2$ & $1260 \pm 13$ & $1678 \pm 14$ & $10.2 \pm 0.5$ & $0.15 \pm 0.01$ & $533 \pm 7$ \\
\hline CrB-AR & $9.4 \pm 1.1$ & $8.1 \pm 0.8$ & $27.0 \pm 1.7$ & $1021 \pm 17$ & $1517 \pm 22$ & $11.6 \pm 0.7$ & $0.18 \pm 0.005$ & $460 \pm 13$ \\
\hline CrB-HT & $10.6 \pm 0.6$ & $6.1 \pm 0.3$ & $151.4 \pm 2.9$ & $1229 \pm 13$ & $1657 \pm 15$ & $14.5 \pm 0.4$ & $0.14 \pm 0.01$ & $537 \pm 7$ \\
\hline R350HT & $12.4 \pm 0.9$ & $8.1 \pm 0.4$ & $36.2 \pm 3.1$ & $746 \pm 11$ & $1245 \pm 16$ & $12.5 \pm 0.6$ & $0.24 \pm 0.005$ & $350 \pm 10$ \\
\hline
\end{tabular}

\subsection{Fracture Surface Analysis}

Figure 5 shows the fracture surface analysis of the broken tensile samples, which were characterized using LOM. During ductile fracture, extensive plastic deformation occurs, which leads to necking. The necking is followed by the void formation and coalescence of these voids to form cracks. These cracks propagate in the material, and the failure leads to a cup-and-cone-type fracture surface. In contrast to ductile fracture, brittle fracture happens with limited plastic deformation. Cracks propagate rapidly, and their direction is perpendicular to the applied load, leaving a fracture surface equal to the cross section of the sample. In Figure 5a,b, the fracture surface of the as-received and heat-treated B360 steel in 2D and 3D is shown. It can be observed that after the heat treatment, this steel becomes more ductile, and the fracture area changes from brittle like to a cup-and-cone form. Using Equation (1), the B360-AR and B360-HT show the $\Delta A$ value of $34.3 \pm 1.5 \%$ and $82.1 \pm 1.4 \%$, respectively. Figure $5 c, d$ illustrates the fracture surface of B1400-AR and B1400-HT, respectively. It can be observed that B1400-AR is not fracturing in a complete brittle way as in the case of other as-received bainitic steels and pearlitic $\mathrm{R} 350 \mathrm{HT}$. Isothermal bainitic heat treatment at $330^{\circ} \mathrm{C}$ for $1 \mathrm{~h}$ makes this steel even more ductile than compared to in as-received condition with an increase in $\Delta \mathrm{A}$ from $63.4 \pm 2.1 \%$ to $81.1 \pm 1.2 \%$.

Figure $5 \mathrm{e}, \mathrm{f}$ shows the fracture surface of $\mathrm{CrB}$ steels before and after isothermal heat treatment. CrB-AR fractures in a brittle like manner while after the heat treatment, this steel shows much more ductile fracture behavior with a cup-and-cone fracture surface. The value $\triangle A$ in $\mathrm{CrB}$ steels increases from $23.9 \pm 1.7 \%$ to $78.2 \pm 2.1 \%$ after the isothermal heat treatment. R350HT pearlitic steel shows the least ductile fracture behavior with an $\Delta A$ of $30.5 \pm 2.6 \%$ and shows a brittle like fracture surface (Figure $5 \mathrm{~g}$ ). To conclude the fracture surface analysis, we observe that the microstructure after heat treatment causes a much more ductile behavior (as was also observed from tensile tests data) with a higher $\Delta A$ percentage (and hence higher true fracture strain) compared to as-received cases. Except for B1400-AR which showed a cup-and-cone fracture surface (for the reason which is explained in Section 3.5), all the other as-received samples show a brittle type fracture surface.

It is reported that high tensile strength rail steels are less susceptible to RCF damage [43]. Therefore, the preferred situation would be the design of high-strength steels, one variant of which is achieved via the isothermal bainitic transformation. Considering the comparison of the mechanical properties and RCF damage resistance among all steels, B360-HT would be the best choice due to its very high strength, good ductility and toughness. 

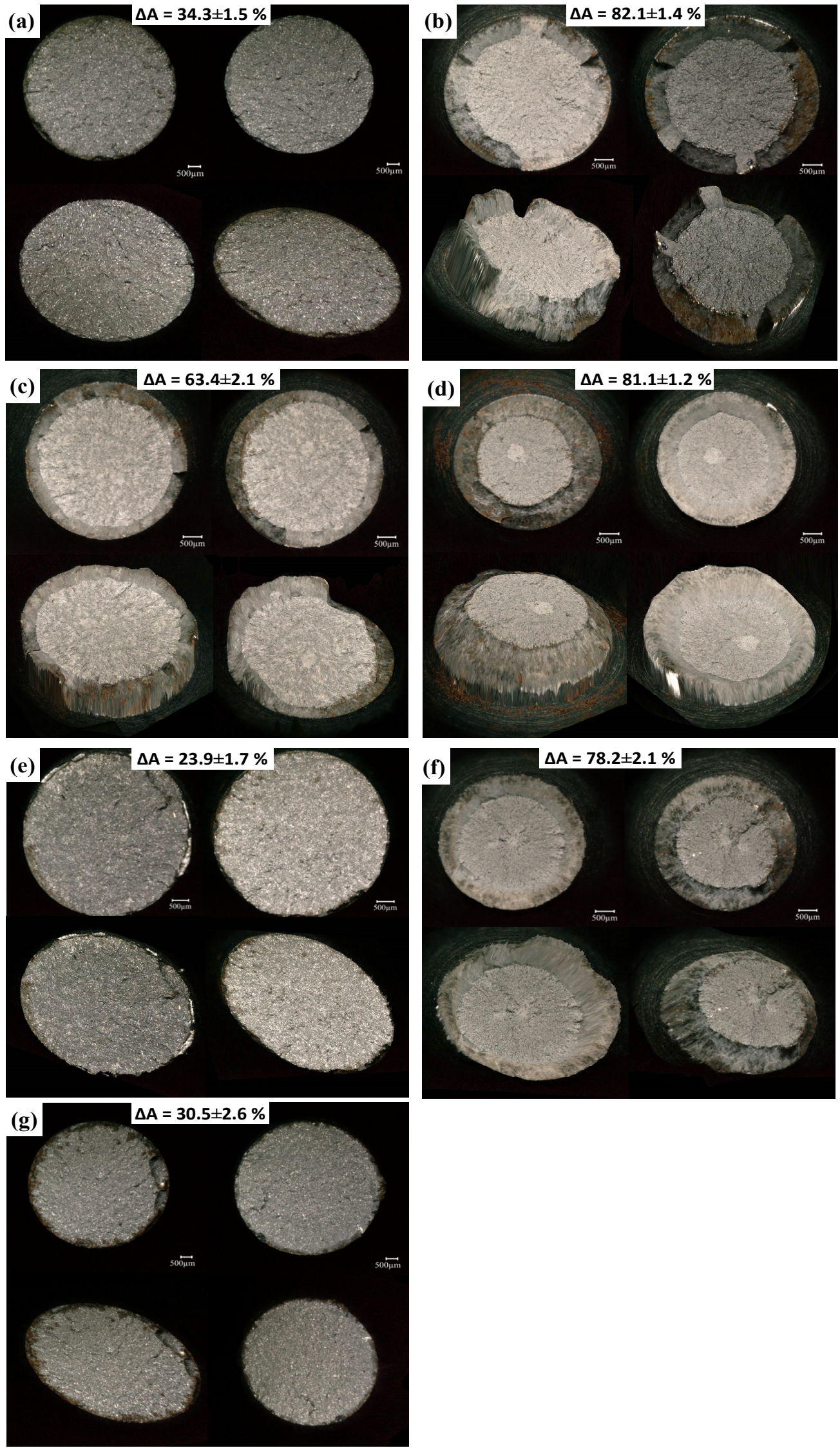

Figure 5. The fracture surfaces and reduction of area $(\triangle A)$ of all tensile samples, up (2D image) and down (3D image); (a) B360-AR, (b) B360-HT, (c) B1400-AR, (d) B1400-HT, (e) CrB-AR, (f) CrB-HT and (g) R350HT. 


\subsection{Hardness}

The hardness of the steel grades was measured and compared, as shown in Figure 6. It is observed that hardness increases after the heat treatment for all steel grades. In general, all heat-treated steels and B1400-AR show hardness value above 500 HV. R350HT has the lowest hardness among all steels. Grain size and the phase fraction of harder phases (such as martensite) have large influence on the hardness values, which is further explained in Section 3.5.

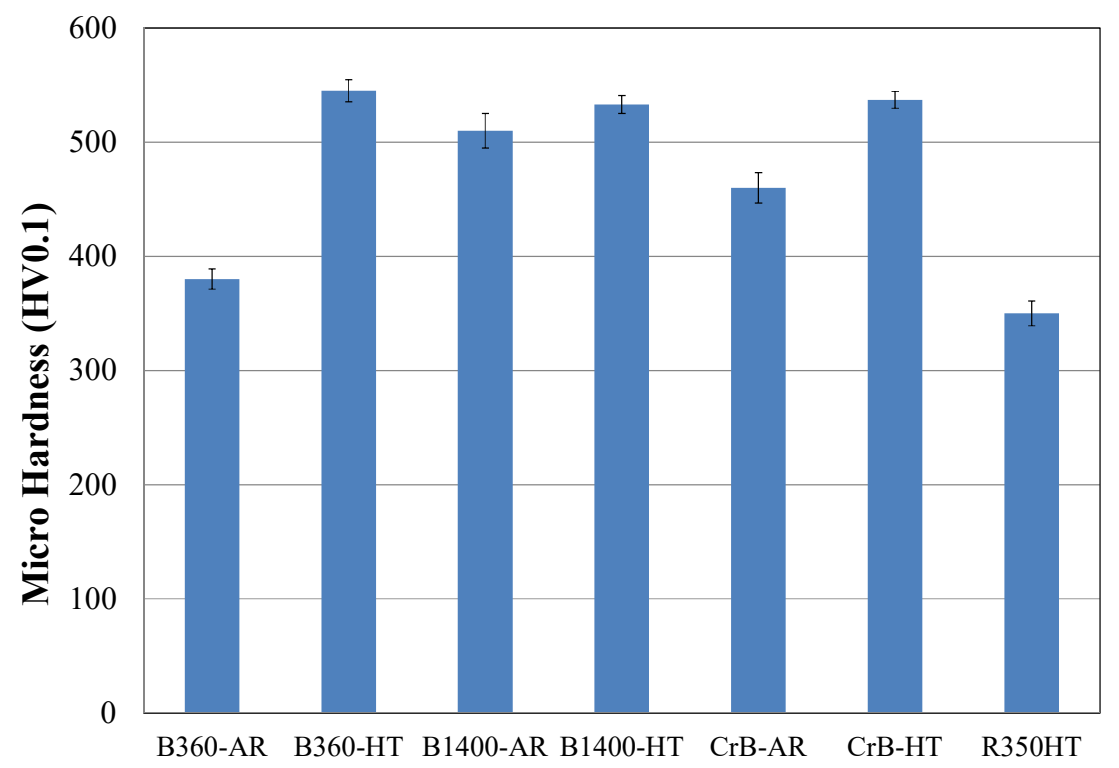

Figure 6. Hardness of all steels (HV0.1).

\subsection{Influence of Microstructure on Mechanical Properties}

There have been several studies on the relationship between the mechanical properties and damage development in rail steels [43-45]. One of these studies showed that using steels with higher hardness and tensile strength reduces the wear and RCF damage in rails [43]. Although it is believed that using softer rails helps removing the RCF cracks, the RCF damage development is also influenced by the wear rate of the steels. Due to faster wear, the rail profile changes, and the contact patch becomes larger, which eventually leads to lower contact stresses in the wheel-rail interface [43]. A study on the German railways showed that not only the wear but also the RCF (head checks) crack growth was reduced significantly by using head-hardened 350HT rails compared to the pearlitic 220, 260 rail grades [44]. The 220 grade had the highest crack depth and 350HT the lowest [44]. In another study, it was shown that, with an increase in the rail hardness, the wear in rail will decrease but, depending on the wheel hardness, wheel wear can increase or remain constant. In this case, if the wheel is harder than the rail, wheel wear increases, and if the wheel is softer than the rail, wheel wear remains constant. However, in both cases, increasing rail hardness reduces overall system wear [45].

As was mentioned, mechanical properties and failure in steels are strongly governed by their microstructures. The bainitic steels in as-received condition are complex mixtures of upper and lower bainite in combination with martensite and carbides. The lower the bainitic transformation temperature, the finer the bainitic structure is, and it results in higher hardness, toughness and wear resistance [46]. Furthermore, minimizing the martensite and cementite fractions in the microstructure contributes to improved damage resistance [46]. In another study, the comparison between bainitic structures isothermally transformed at $330{ }^{\circ} \mathrm{C}$ (lower bainite) and $425^{\circ} \mathrm{C}$ (upper bainite) showed that steels with lower bainite structure have finer and more uniform distribution of carbides and lower bainitic ferrite plates. Together with the higher dislocation density in lower bainite, this results in higher tensile strength, elongation and impact energy properties than for the upper bainite [47]. In the 
next sections, the difference in the microstructure of the bainitic steels, the effect of isothermal heat treatment on their microstructure and the influence of microstructure on the measured mechanical properties are discussed based on the results obtained via LOM, SEM and EBSD.

We did investigation on the samples using LOM on polished and non-etched samples at magnification up to $250 \times$, and we did not find any visible non-metallic inclusions (MnS or oxides) at this magnification (see Figure S1).

\subsubsection{B360 Grade}

Figure 7a shows the LOM of the carbide-free bainitic B360-AR. The continuous cooling causes the bainitic transformation in different temperature ranges to form two morphologies of bainite, i.e., upper bainite (UB) and lower bainite (LB). The UB is formed at relatively high temperature just below bainitic start temperature, while LB, which has a lamellar structure of lath bainitic ferrite (BF) and thin film retained austenite (TFRA), forms at rather low temperature just above martensitic start temperature [27-30]. Simultaneously, the formation of bainite during the continuous cooling is not complete due to limited transformation time. This leads to large areas of untransformed retained austenite (RA), which later remains as blocky retained austenite (BRA) or transforms into martensite (M). In Figure 7a, locations of LB, which is a lamellar structure consisting of BF (dark) and TFRA (bright) lamellae, and also locations of bright patches of M/BRA can be observed. Figure 8a shows the SEM image of B360-AR microstructure, indicating the presence of fine bainite (LB), coarse bainite (UB) and islands of blocky retained austenite (BRA) and martensite (M).

It is common design strategy in bainitic steels to avoid incomplete bainitic transformation, since the remaining austenite (which does not transform into bainite) could later transform into martensite during further cooling or under mechanical load. This brittle $\mathrm{M}$ phase reduces the toughness of the steel [48]. For this purpose, low transformation temperature at $330^{\circ} \mathrm{C}$ was selected for isothermal heat treatment and enough time was given to maximize the bainitic fraction (Figure 3). This also leads to formation of a fine bainitic microstructure with good mechanical properties, as shown above. The resulting carbide-free low bainitic microstructure in B360-HT (Figures 7b and 8b) contains mainly fine lath bainitic ferrite and thin film retained austenite with small-sized homogeneously distributed blocky retained austenite, whereas B360-AR has a microstructure of low bainite and large zones (islands) of blocky retained austenite and martensite (Figures 7a and 8a).

The small-size BRA islands observed in B360-HT usually contain higher carbon concentration due to carbon partitioning during the bainite formation and are mechanically and thermally more stable [48-52]. The carbide-free fine bainitic microstructure of B360-HT consists of approximately $2.2 \pm 1.0 \%$ of blocky retained austenite (BRA) having an average size of $463 \pm 61 \mathrm{~nm}$, as shown in Table 4. Another research, which was performed on the carbide-free bainitic steel with the same composition and isothermal bainitic treatment, shows that the BRA islands less than $250 \mathrm{~nm}$ in size in carbide-free bainitic steels are mechanically stable and do not transform into martensite during the tensile fracture [53]. Thus, the BRA islands in B360-HT will partially transform into martensite during the tensile fracture and small BRA islands $(<250 \mathrm{~nm})$, and TFRA would be stable during the tensile fracture. The mechanical stability of the small BRA islands is governed by the $C$ enrichment in these islands due to high bainitic ferrite fraction [54,55]. Furthermore, thin film retained austenite (TFRA) in this steel is even more mechanically stable than BRA due to constraints from bainitic ferrite, high defect density in the TFRA due to displacive bainitic transformation and high C enrichment (up to 8 at. \%) [53]. As mentioned above, the BRA fraction in B360HT is small (2.2 $\pm 1 \%)$, and the partial transformation to martensite will not affect the local strain partitioning and damage significantly [53]. In the same study, it is shown that the strain partitioning in this steel was homogenous due to its uniform microstructure, which leads its good mechanical performance and high damage resistance [53].

Large BRA present in B360-AR is less stable to transformation due to the lower carbon content in large blocks, which contributes to an increase in the martensitic fraction upon mechanical loading via strain induced transformation of austenite into martensite [54]. This transformation increases the 
overall fraction of brittle martensite phase in the microstructure, which leads to brittle-like fracture response (Figure 5) and lower toughness [48]. It was shown that in B360-AR bainitic steel, micro-cracks initiate primarily at the weak interfaces between martensite and bainitic ferrite. [55-57].

Figure 9a shows superimposed Image Quality (IQ) and phase maps of the B360-HT steel. The maps illustrate that there is mainly bainite (LB) and BRA with area fraction of $97.8 \pm 1.0 \%$ and 2.2 $\pm 1.0 \%$, respectively (Table 4). The average calculated bainitic lath diameter is $2391 \pm 348 \mathrm{~nm}$, and average grain diameter for blocky retained austenite is $463 \pm 61 \mathrm{~nm}$ (Table 4). We do not observe areas with low IQ in Figure 9a. This indicates that there is no M present in the B360-HT microstructure. This explanation is based on the fact that the martensite phase contains a high dislocation density, which deteriorates the IQ in the EBSD measurements [49-51]. The ductile fracture of the B360-HT steel is due to its carbide/martensite free fine bainitic microstructure. The brittle microstructural constituents, such as cementite and martensite, are not present in the microstructure due to high Si content and isothermal bainitic transformation, respectively.

In conclusion, the isothermal bainitic heat treatment leads to the avoidance of martensite and large blocky retained austenite and also produces much finer bainitic structure as LB, which primarily contains more stable TFRA laths sandwiched between lath BF.

\subsubsection{B1400 Grade}

The B1400 steels contain lower concentration of Si than the carbide-free B360 grade (Table 1). $\mathrm{Si}$ suppresses the precipitation of carbide (cementite) from retained austenite [36,37]. This is why B1400 steels are prone to having bainitic ferrite together with carbides in the microstructure during bainitic transformation. The microstructures of B1400-AR and B1400-HT are presented in Figure $7 \mathrm{c}, \mathrm{d}$, respectively.

As can be observed in Figure 7c, B1400-AR contains finer bainitic microstructure compared to the other two as-received steels. The reason, as mentioned before, is that the as-received steel was treated in an isothermal bainitic transformation at $400{ }^{\circ} \mathrm{C}$ for $30 \mathrm{~min}$ (in industry). The higher bainitic transformation temperature leads to a coarser bainitic microstructure [46]. The holding time for bainitic transformation for the rails was not sufficiently long so that it led to the presence of some BRA/M islands in the microstructure. Figure 7c shows the presence of lower bainite together with M/BRA islands. Looking at higher magnification in Figure $8 \mathrm{c}$ indicates the presence of carbide (cementite) precipitates. These carbides exist in two different morphologies, i.e., spherical and lath-shaped. The geometrical measurements of these carbides were done using image processing tools in the ImageJ software in different locations on the SEM image (Figure 8c). Based on these measurements, the average diameter of the spherical carbides is $144 \pm 28 \mathrm{~nm}$, and the average thickness of lath-shaped carbides is $128 \pm 15 \mathrm{~nm}$ (Table 5). The average distance between the carbides in B1400-AR is also obtained using combination of ImageJ software and MATLAB. This distance was measured to be $1225 \pm 89 \mathrm{~nm}$ (Table 5).

We performed isothermal heat treatment on B1400-AR steels at $330{ }^{\circ} \mathrm{C}$ for $1 \mathrm{~h}$, and relatively fine bainitic microstructure is obtained after this heat treatment, as shown in Figures $7 \mathrm{~d}$ and $8 \mathrm{~d}$. The resulting microstructure contains nano-sized carbides (NSC) with average diameter of $106 \pm 21 \mathrm{~nm}$, which is smaller than the measured diameter for B1400-AR $(144 \pm 28 \mathrm{~nm})$, as can be seen in Table 5 . The average distance between these NSCs was measured to be $620 \pm 89 \mathrm{~nm}$ (compared to $1225 \pm 89 \mathrm{~nm}$ for B1400-AR), as can also be seen in Table 5. This shows that NSCs, which precipitate within the lower BF laths, are smaller and more closely spaced inside B1400-HT compared to B1400-AR. These NSCs are expected to act as obstacles to the dislocation motion and will improve the yield strength of the B1400-HT steel [58]. Figure 8d also shows the presence of inter-lath thin film retained austenite (TFRA) in between the BF laths. On the other hand, the relatively longer holding period maximizes the bainitic fraction (with LB morphology) and suppresses the martensitic transformation. No M is present in B1400-HT, as indicated by IQ data shown in Figure 9b. This enhances the ductility of the heat-treated steel and leads to more ductile fracture response compared to as-received condition (Figure 5). There are still islands of BRA, as shown in Figure 8d. The green color in Figure 9b shows the BRA inside the 
B1400-HT microstructure with fraction of $2.8 \pm 0.7 \%$, as given in Table 4 . The average lath diameters of bainite and BRA grain diameter inside B1400-HT are $2641 \pm 478 \mathrm{~nm}$ and $530 \pm 71 \mathrm{~nm}$ respectively (Table 4).

To summarize, the finer bainitic microstructure of B1400-HT than B1400-AR and avoidance of M phase in B1400-HT, containing closely spaced nano-sized carbides (NSCs) inside the bainitic laths and also presence of small BRA, which is more stable than bigger islands of BRA, produce a microstructure with better strength and ductility compared to as-received steel.

\subsubsection{CrB Grade}

The LOM and SEM images of CrB-AR microstructure are shown in Figures 7e and 8e. This steel contains brittle phases like martensite and carbides due to incomplete bainitic transformation. Presence of these phases leads to poor mechanical properties and more brittle fracture response (Figure 5). Carbides are considered to be bad for fatigue life as well [48]. The geometrical properties of the carbides were also measured using the same method as used for B1400. The average diameter of the carbides is $127 \pm 24 \mathrm{~nm}$, and the average distance between these carbides is $1069 \pm 55 \mathrm{~nm}$ (Table 5). Isothermal heat treatment is performed on this steel to suppress the untransformed regions of austenite by maximizing bainitic transformation. This suppresses the formation of brittle martensite in the microstructure. A much finer microstructure compared to CrB-AR results (comparing Figures 7e and $7 \mathrm{f}$ ). Looking at higher magnification in Figure $8 \mathrm{f}$ shows that the microstructure after the heat treatment primarily contains LB (combination of BF, TFRA and NSC) with smaller size BRA islands (compared to as-received microstructure). Comparing Figures $8 \mathrm{e}$ and $8 \mathrm{f}$ shows that there is a change in shape and size of carbides. The average diameter of these carbides was measured to be $79 \pm 13 \mathrm{~nm}$, and the average distance between them was $550 \pm 21 \mathrm{~nm}$ (Table 5). This means CrB-HT has smaller carbides (mostly as NSC), which are closely spaced with respect to each other and this increases the yield strength of CrB-HT compared to the as-received condition [58].

According to EBSD maps of CrB-HT presented in Figure 9c-e, there is still 3.8\% M (as darker areas) present in the microstructure (in contrast to no $\mathrm{M}$ in other two heat-treated steels). Figure $9 \mathrm{~d}$ illustrates the $\mathrm{M}$ islands distribution in CrB-HT, while Figure 9e shows the distribution of BRA phase in addition to $\mathrm{M}$. The main difference of CrB-HT compared to other two heat-treated steels is the presence of $\mathrm{M}$. This can be due to the fact that the $\mathrm{CrB}$ grade contains high concentration of $\mathrm{Cr}(3 \mathrm{wt} \%)$. High content of Cr slows down the bainitic transformation kinetics [59-61]. This is why the CrB-HT contains a lower bainitic fraction than B360-HT or B1400-HT for a given isothermal holding time, which naturally means that there is higher fraction of untransformed regions in the microstructure in the same heat-treatment condition. From EBSD phase map for CrB-HT, there is $3.3 \pm 0.8 \%$ BRA with average grain diameter of $327 \pm 55 \mathrm{~nm}$ and bainite with average lath diameter of $2100 \pm 358 \mathrm{~nm}$, as shown in Table 4 .

Comparing CrB-AR and CrB-HT, it appears that the isothermal heat treatment creates finer microstructure with smaller BRA islands and more uniform distribution of closely spaced nano-sized carbides inside the bainitic laths in these steel grades that reflects the better mechanical properties in the heat-treated steel compared to as-received one.

For all the heat-treated samples, we did the reconstruction of the prior austenite grains (PAGs) to see if there were any significant differences in the prior austenite grain size (PAGS) of different steels. However, the observed difference in PAGS is not significant and does not exceed 8\% (see Figure S2). It should be noted that the difference in bainitic lath sizes in the heat-treated steels would not be significantly affected by such small difference in PAGS. This difference in bainitic lath sizes (Table 4) would primarily be due to the difference in chemical composition of different steels than their PAGS. For more information about PAGS calculations, the reader is referred to the Table S1 of the article. 
Table 4. The comparison of microstructural constituents in heat-treated samples.

\begin{tabular}{ccccc}
\hline Steel & $\begin{array}{c}\text { Bainite Average Lath } \\
\text { Diameter } \mathbf{( n m})\end{array}$ & $\begin{array}{c}\text { BRA Area Fraction } \\
\mathbf{( \% )}\end{array}$ & $\begin{array}{c}\text { BRA Average Grain } \\
\text { Diameter (nm) }\end{array}$ & $\begin{array}{c}\text { Martensite Area } \\
\text { Fraction (\%) }\end{array}$ \\
\hline B360-HT & $2391 \pm 348$ & $2.2 \pm 1.0$ & $463 \pm 61$ & $\sim 0$ \\
B1400-HT & $2641 \pm 478$ & $2.8 \pm 0.7$ & $530 \pm 71$ & $\sim 0$ \\
CrB-HT & $2100 \pm 358$ & $3.3 \pm 0.8$ & $327 \pm 55$ & $3.8 \pm 0.9$ \\
\hline
\end{tabular}

Table 5. The morphological characteristics of carbides in B1400 and CrB steels.

\begin{tabular}{cccc}
\hline Steel & $\begin{array}{c}\text { Average Carbide Size } \\
\text { (diameter) }(\mathbf{n m})\end{array}$ & $\begin{array}{c}\text { Average Distance } \\
\text { between Carbides } \mathbf{( n m})\end{array}$ & $\begin{array}{c}\text { Average Width of } \\
\text { Lath-Shaped Carbides (nm) }\end{array}$ \\
\hline B1400-AR & $144 \pm 28$ & $1225 \pm 89$ & $128 \pm 15$ \\
B1400-HT & $106 \pm 21$ & $620 \pm 89$ & - \\
CrB-AR & $127 \pm 24$ & $1069 \pm 55$ & - \\
CrB-HT & $79 \pm 13$ & $550 \pm 21$ & - \\
\hline
\end{tabular}
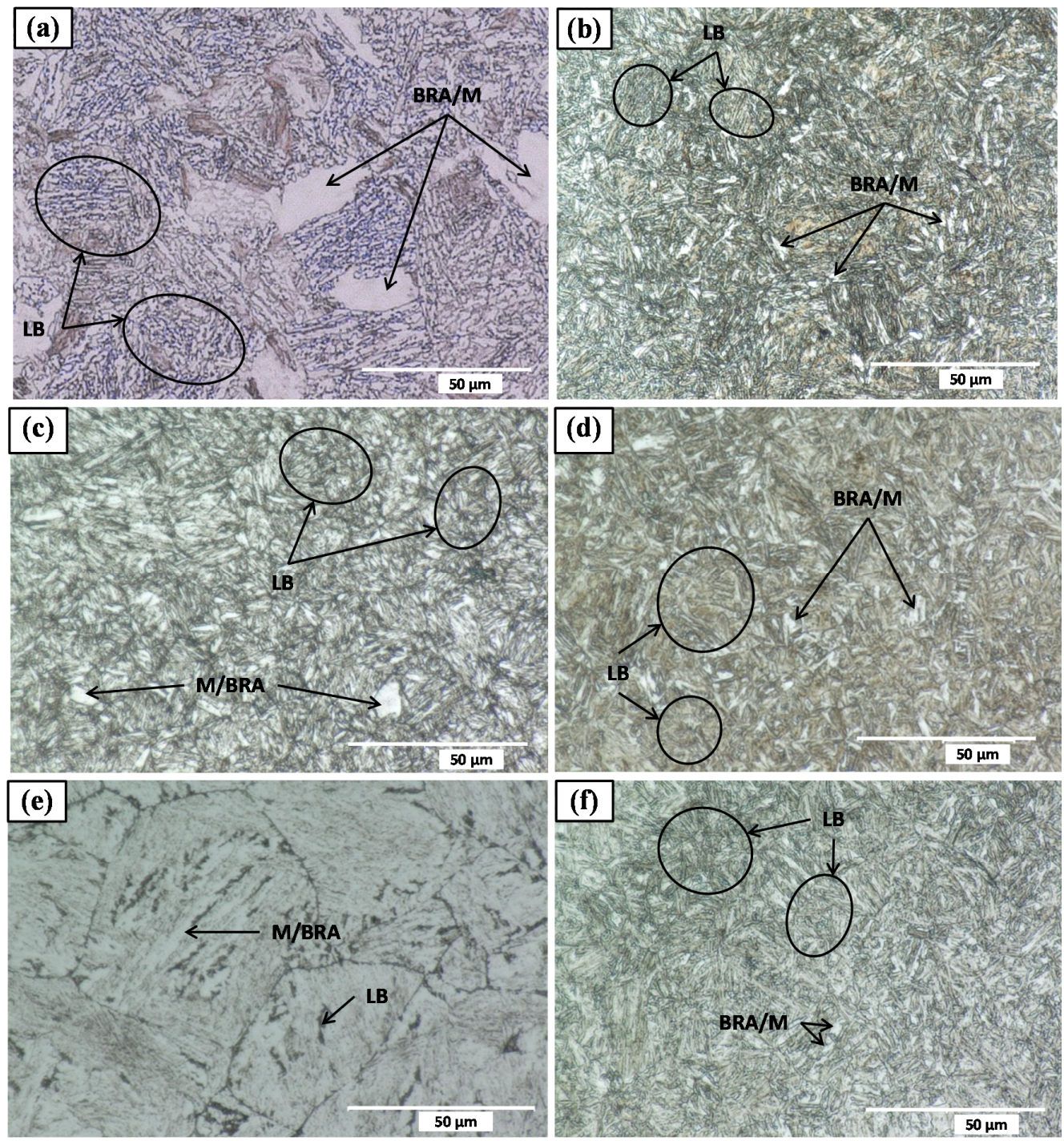

Figure 7. Light optical microscopy LOM images of all bainitic steels; (a) B360-AR, (b) B360-HT, (c) B1400-AR and (d) B1400-HT, (e) CrB-AR, (f) CrB-HT. 

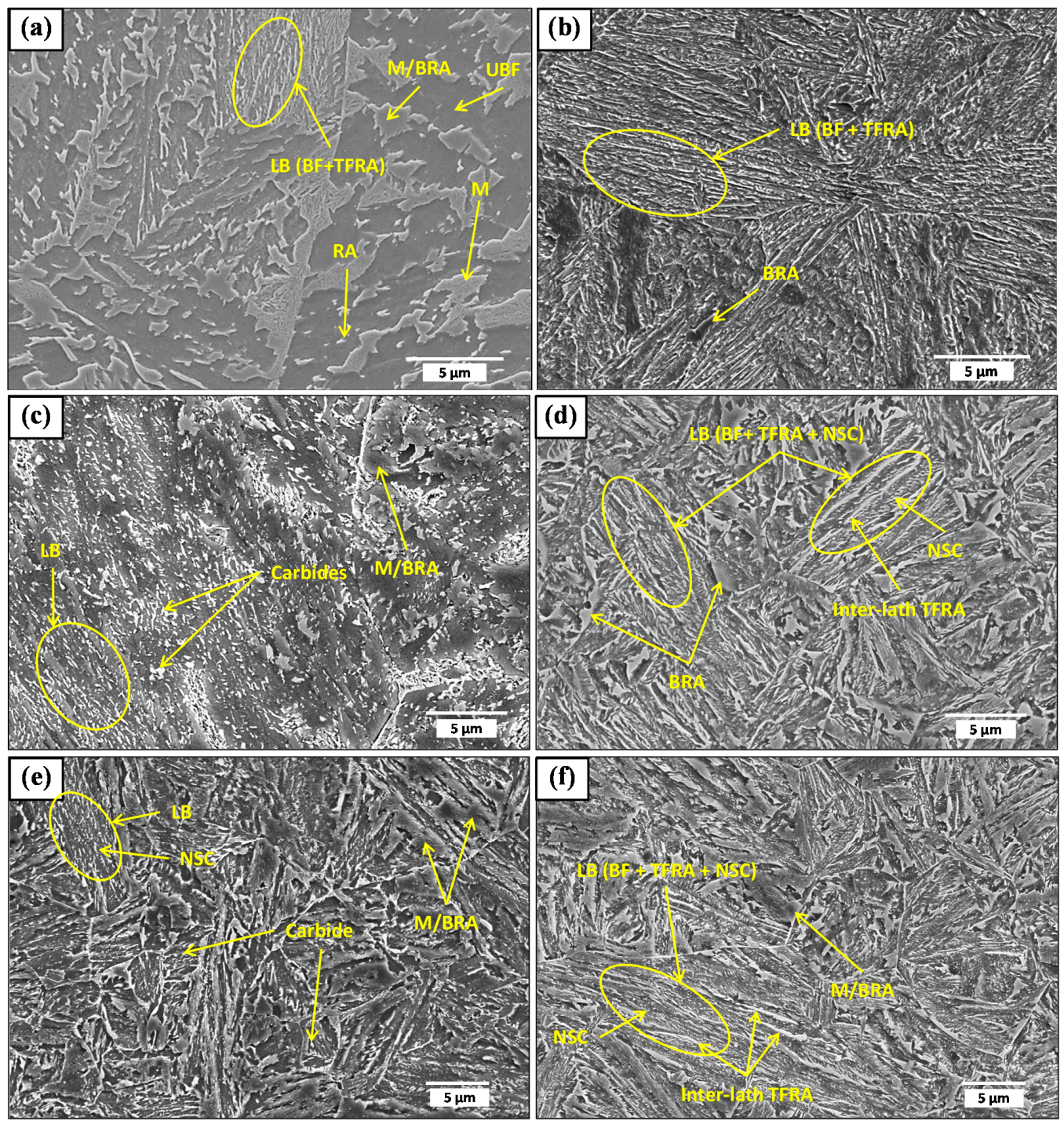

Figure 8. SEM images of all bainitic steels; (a) B360-AR, (b) B360-HT, (c) B1400-AR, (d) B1400-HT, (e) CrB-AR, (f) CrB-HT.

In conclusion, investigating the microstructure of the bainitic steels reveals valuable information about the root causes of the measured mechanical properties. This investigation would give us good insight to choose the suitable material for our purpose. Since carbides have a bad effect on the fatigue properties of steels, B360-HT can be a good candidate in the case of fatigue loading. This steel also has high hardness (533 HV0.1) with a finer bainitic microstructure without any martensite or carbide. This would result in good resistance to wear and RCF damage development [46]. Thus, B360 carbide-free bainitic steel after an isothermal heat treatment is a good candidate to manufacture rails and S\&Cs.

The loading in rails and switches and crossings (S\&Cs) is different from and more complex than tensile load. Rails face the combination of compression and shear. However, the S\&Cs are subjected to heavy dynamic impact loads. In future, a fatigue load combining shear and compression tests can be carried out to acquire more information regarding the material reaction to this kind of loading. Impact resistance of the material should also be investigated. Another important material property is the fracture toughness. Usually, rolling contact fatigue crack grows slowly and steadily up to a certain length but after this critical crack length, propagation rate increases rapidly. Fracture toughness gives good insight regarding the crack growth rate and the critical crack length for RCF damage development in steels. The results of these tests combined and their interaction with the material microstructure 
could help to make an optimal design. These optimal designs can be used in different parts of railway infrastructure and ultimately lead to more sustainable railway networks.

It should be taken into consideration that, in order to reduce the damage in rails and S\&Cs, not only must the right material for each section of a railway track be chosen but there should also be a good control of the loads on the rail during wheel-rail contact. These loads are dependent on factors such as track geometrical characteristics, train suspension system, track stiffness and damping characteristics, tribological properties and lubrication condition of wheel-rail interface.
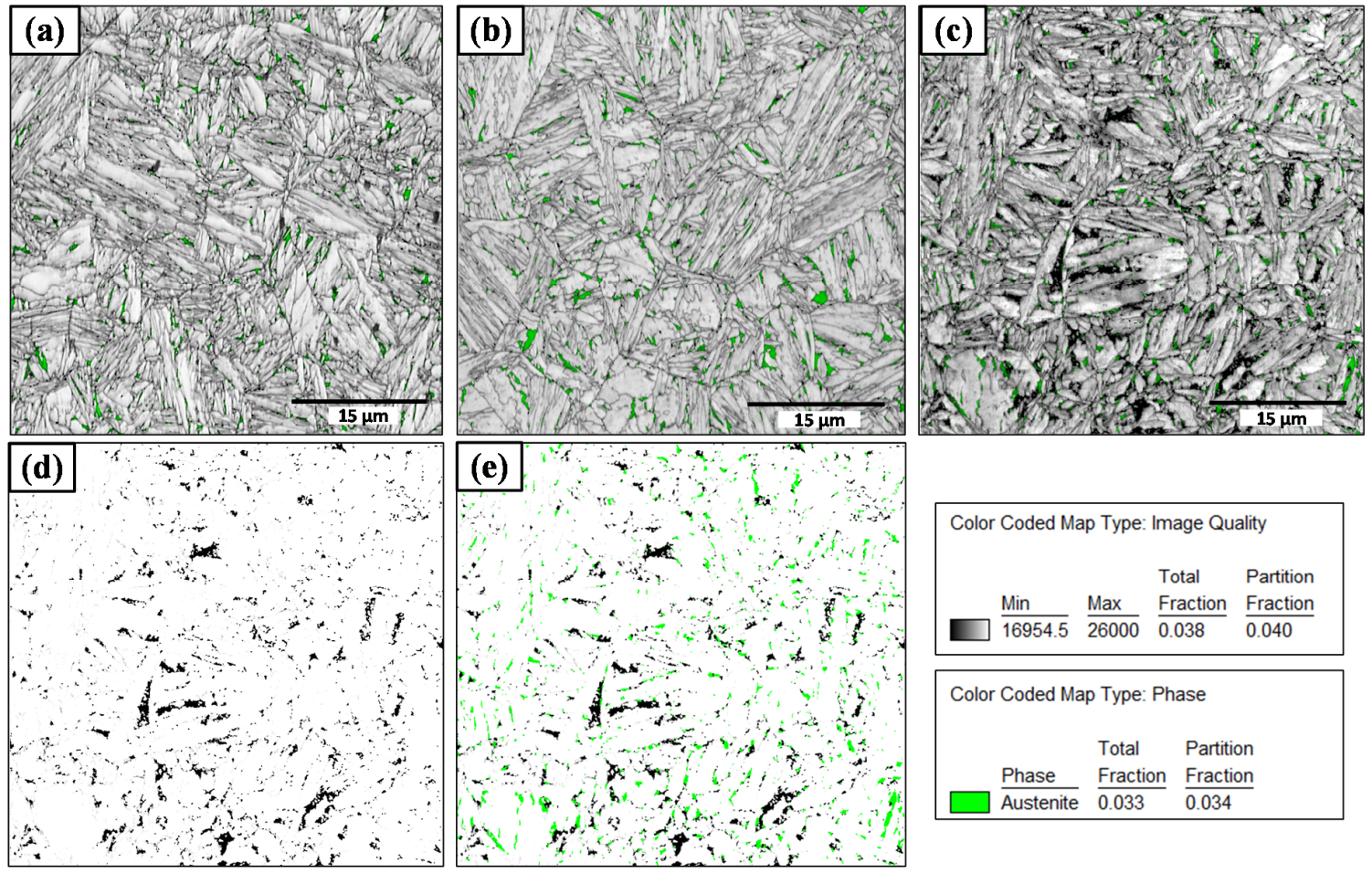

Figure 9. Electron backscatter diffraction (EBSD) maps of heat-treated grades; (a) image quality (IQ) and phase map of B360-HT, green color representing austenite phase, (b) IQ and phase map of B1400-HT, (c) IQ and phase map of CrB-HT, (d) IQ map of CrB-HT showing the M phase distribution (black),

(e) IQ map and phase map of CrB-HT showing the M and austenite phase distribution.

\section{Conclusions}

The mechanical properties of three bainitic grades B360, B1400 and CrB in as-received and heat-treated conditions together with R350HT pearlitic steel were compared. For this purpose, uniaxial tensile tests and hardness measurements were performed on all steels. To study the influence of the microstructure on mechanical properties of bainitic steels, imaging techniques such as LOM, SEM and EBSD were used. The main conclusions of this study are as follows:

- $\quad$ All three bainitic steels (irrespective of the heat treatment) perform better than the pearlitic R350HT steel regarding tensile strength, ductility and hardness.

- $\quad$ By using low bainitic transformation temperature and providing enough time for it, nearly complete bainitic transformation is achieved. As a result, a finer bainitic microstructure with smaller-size blocky retained austenite (BRA) results (in comparison to the as-received steel), with almost no martensite (M). This change in the microstructure results in better mechanical properties.

- $\quad$ For B1400-HT and CrB-HT grades, isothermal heat treatment results in smaller size of carbides (in comparison to the as-received steel), which are closely spaced to each other (mostly inside the bainite laths). This results in higher yield strength in heat-treated grades compared to as-received conditions. 
- The hardness of bainitic steels increases with heat treatment due to production of large fraction of lower bainite (LB), which is finer, stronger and harder than upper bainite (UB).

- $\quad$ The highest strength, ductility and toughness among all steels investigated here were obtained in B360-HT. These improved properties are associated with the absence of carbides and martensite and formation of fine bainitic microstructure, which consists of bainitic ferrite (BF) laths, thin film retained austenite (TFRA) and small and homogeneously distributed BRA.

Supplementary Materials: The following are available online at http://www.mdpi.com/2075-4701/9/7/778/s1, Figure S1: Optical Micrographs of different steels in non-etched condition (a) B360, (b) B1400, (c) CrB, Figure S2: (a) Grain map showing the PAGs for B360-HT, (b) PAGs for B1400-HT, (c) PAGs for CrB-HT, (d) the grain size distribution for all steels, Table S1: PAGS for heat treated steels.

Author Contributions: O.H. and A.K. were involved in writing, designing and performing the experiments presented in this manuscript. O.H. did the data analysis. Z.L., R.H.P., J.S. and R.D. were involved in scientific discussions, supervision, reviewing and editing of the manuscript. Z.L. and R.D. have acquired the funding for this work.

Funding: This research was funded by ProRail, Netherlands and Materials innovation institute M2i, Netherlands under the research grant number T91.1.12475a.

Acknowledgments: This research was partly carried out under project number T91.1.12475a in the framework of the research program of the Materials innovation institute M2i (www.m2i.nl).

Conflicts of Interest: The authors declare no conflict of interest.

\section{References}

1. Clayton, P.; Allery, M.B.P. Metallurgical Aspects of Surface Damage Problems in Rails. Can. Met. Q. 1982, 21, 31-46. [CrossRef]

2. Dollevoet, R. Design of an Anti Head Check profile based on stress relief. Ph.D. Thesis, University Library/University of Twente, Enschede, The Netherlands, 2010.

3. Dollevoet, R.; Li, Z.; Arias-Cuevas, O. A Method for the Prediction of Head Checking Initiation Location and Orientation under Operational Loading Conditions. Proc. Inst. Mech. Eng. Part F J. Rail Rapid Transit 2010, 224, 369-374. [CrossRef]

4. Li, Z.; Zhao, X.; Esveld, C.; Dollevoet, R.; Molodova, M. An investigation into the causes of squats-Correlation analysis and numerical modeling. Wear 2008, 265, 1349-1355. [CrossRef]

5. Deng, X.; Qian, Z.; Li, Z.; Dollevoet, R. Investigation of the formation of corrugation-induced rail squats based on extensive field monitoring. Int. J. Fatigue 2018, 112, 94-105. [CrossRef]

6. Wei, Z.; Núñez, A.; Boogaard, A.; Dollevoet, R.; Li, Z. Method for evaluating the performance of railway crossing rails after long-term service. Tribol. Int. 2018, 123, 337-348. [CrossRef]

7. Ueda, M.; Uchino, K.; Kobayashi, A. Effects of carbon content on wear property in pearlitic steels. Wear 2002, 253, 107-113. [CrossRef]

8. Hyzak, J.M.; Bernstein, I.M. The role of microstructure on the strength and toughness of fully pearlitic steels. Met. Mater. Trans. A 1976, 7, 1217-1224. [CrossRef]

9. Krauss, G.; Grossmann, M.A. Principles of heat treatment of steel; American Society for Metals: Metals Park, OH, USA, 1980; pp. 1890-1952.

10. Kavishe, F.P.L.; Baker, T.J. Effect of prior austenite grain size and pearlite interlamellar spacing on strength and fracture toughness of a eutectoid rail steel. Mater. Sci. Technol. 1986, 2, 816-822. [CrossRef]

11. Gladman, T. Material Science and Technology; Wiley-VCH Verlag GmbH \& Co. KGaA: Weinheim, Germany, 2006; pp. 402-432.

12. Pickering, F.B. Structure-Property Relationships in Steels. In Material Science and Technology; Wiley-VCH Verlag GmbH \& Co. KGaA: Weinheim, Germany, 2006; pp. 43-81.

13. Pérez-Unzueta, A.J.; Beynon, J.H. Microstructure and wear resistance of pearlitic rail steels. Wear 1993, 162, 173-182. [CrossRef]

14. Clayton, P.; Danks, D. Effect of interlamellar spacing on the wear resistance of eutectoid steels under rolling-sliding conditions. Wear 1990, 135, 369-389. [CrossRef] 
15. Bouse, G.; Bernstein, I.; Stone, D. Role of Alloying and Microstructure on the Strength and Toughness of Experimental Rail Steels. In Rail Steels_Developments, Processing, and Use; ASTM International: West Conshohocken, PA, USA, 1978.

16. Marich, S.; Curcio, P. Development of High-Strength Alloyed Rail Steels Suitable for Heavy Duty Applications. In Rail Steels-Developments, Processing, and Use; ASTM International: West Conshohocken, PA, USA, 1978.

17. Smith, Y.E.; Fletcher, F.B. Alloy steels for high-strength, as-rolled rails. Am. Soc. Test. Mater. Spec. Tech. Publ. 1978, 11, 212-232. Available online: http://inis.iaea.org/search/search.aspx?orig_q=RN:10454787 (accessed on 13 September 2018).

18. Han, K.; Mottishaw, T.; Smith, G.; Edmonds, D.; Stacey, A. Effects of vanadium additions on microstructure and hardness of hypereutectoid pearlitic steels. Mater. Sci. Eng. A 1995, 190, 207-214. [CrossRef]

19. Han, K.; Smith, G.D.W.; Edmonds, D.V. Pearlite phase transformation in Si and V steel. Met. Mater. Trans. A 1995, 26, 1617-1631. [CrossRef]

20. Honeycombe, R.W.K.; Bhadeshia, H.K.D.H. Steels: Microstructure and Properties, 2nd ed.; Edward Arnold: New York, NY, USA, 1995.

21. Kumar, A.; Agarwal, G.; Petrov, R.; Goto, S.; Sietsma, J.; Herbig, M. Microstructural evolution of white and brown etching layers in pearlitic rail steels. Acta Mater. 2019, 171, 48-64. [CrossRef]

22. Zuidema, B.K.; Subramanyam, D.K.; Leslie, W.C. The effect of aluminum on the work hardening and wear resistance of hadfield manganese steel. Met. Mater. Trans. A 1987, 18, 1629-1639. [CrossRef]

23. Peters, N.W. The Performance of Hadfield's Manganese Steel as It Relates to Manufacture. Available online: https://www.arema.org/files/library/2005_Conference_Proceedings/00040.pdf (accessed on 12 September 2018).

24. Schmidova, E.; Hlavaty, I.; Hanus, P. The weldability of the steel with high manganese. Teh. Vjesn. Tech. Gaz. 2016, 23, 749-752.

25. Havel, D. Austenitic Manganese Steel: A Complete Overview. Available online: https://www.sfsa.org/doc/ 2017-4.1\%20Columbia\%20-\%20Havel.pdf (accessed on 14 September 2018).

26. Lewis, R.; Olofsson, U. Copyright. In Wheel-Rail Interface Handbook; Woodhead Publishing: Sawston, UK, 2009. [CrossRef]

27. Bain, E.C. Factors affecting the inherent hardenability of steel. J. Heat Treat. 1979, 1, 57-100. [CrossRef]

28. Ohtani, H.; Okaguchi, S.; Fujishiro, Y.; Ohmori, Y. Morphology and properties of low-carbon bainite. Met. Mater. Trans. A 1990, 21, 877-888. [CrossRef]

29. Ohmori, Y. Microstructural Evolutions with Precipitation of Carbides. ISIJ Int. 2001, 41, 554-565. [CrossRef]

30. Azuma, M.; Fujita, N.; Takahashi, M.; Senuma, T.; Quidort, D.; Lung, T. Modelling Upper and Lower Bainite Trasformation in Steels. ISIJ Int. 2005, 45, 221-228. [CrossRef]

31. Krauss, G.; Thompson, S.W. Ferritic Microstructures in Continuously Cooled Low- and Ultralow-carbon Steels. ISIJ Int. 1995, 35, 937-945. [CrossRef]

32. Bakhtiari, R.; Ekrami, A. The effect of bainite morphology on the mechanical properties of a high bainite dual phase (HBDP) steel. Mater. Sci. Eng. A 2009, 525, 159-165. [CrossRef]

33. Tomita, Y.; Okabayashi, K. Mechanical properties of 0.40 pct C-Ni-Cr-Mo high strength steel having a mixed structure of martensite and bainite. Met. Mater. Trans. A 1985, 16, 73-82. [CrossRef]

34. Pickering, F.B. Physical Metallurgy and the Design of Steels; Applied Science Publishers: London, UK, 1978; Available online: http://books.google.com/books?id=k5NTAAAAMAAJ (accessed on 5 August 2018).

35. Bhadeshia, H.K. High Performance Bainitic Steels. Mater. Sci. Forum 2005, 500, 63-74. [CrossRef]

36. Sandvik, B.P.J.; Nevalainen, H.P. Structu re-property relationships in commercial low-alloy bainitic-austenitic steel with high strength, ductility, and toughness. Met. Technol. 1981, 8, 213-220. [CrossRef]

37. Bhadeshia, H.K.D.H.; Edmonds, D.V. Bainite in Silicon Steels New Composition - Property Approach Part 1. Met. Sci. 1983, 17, 411-419. [CrossRef]

38. Long, X.; Kang, J.; Lv, B.; Zhang, F. Carbide-free bainite in medium carbon steel. Mater. Des. 2014, 64, $237-245$. [CrossRef]

39. Wang, Y.; Zhang, F.; Wang, T. A novel bainitic steel comparable to maraging steel in mechanical properties. Scr. Mater. 2013, 68, 763-766. [CrossRef]

40. Sawley, K.; Kristan, J. Development of bainitic rail steels with potential resistance to rolling contact fatigue. Fatigue Fract. Eng. Mater. Struct. 2003, 26, 1019-1029. [CrossRef] 
41. Clayton, P.; Devanathan, R.; Jin, N.; Steele, R.K. A Review of Bainitic Steels for Wheel/Rail Contact. In Rail Quality and Maintenance for Modern Railway Operation; Kalker, J.J., Cannon, D.F., Orringer, O., Eds.; Springer: Dordrecht, The Netherlands, 1993; pp. 41-51. [CrossRef]

42. Hollomon, J.H. Tensile deformation. Trans. AIME 1945, 162, 268-290.

43. Pointner, P. High strength rail steels-The importance of material properties in contact mechanics problems. Wear 2008, 265, 1373-1379. [CrossRef]

44. Heyder, R.; Girsch, G. Testing of HSH®rails in high-speed tracks to minimise rail damage. Wear 2005, 258, 1014-1021. [CrossRef]

45. Lewis, R.; Wang, W.J.; Burstow, M.; Lewis, S.R. Investigation of the Influence of Rail Hardness on the Wear of Rail and Wheel Materials under Dry Conditions Wear and RCF Mechanisms. Proc. Third Int. Conf. Railw. Technol. Res. Dev. Maintenance 2016, 5, 1-17. [CrossRef]

46. Shipway, P.; Wood, S.; Dent, A. The hardness and sliding wear behaviour of a bainitic steel. Wear 1997, 203, 196-205. [CrossRef]

47. Abbaszadeh, K.; Saghafian, H.; Kheirandish, S. Effect of Bainite Morphology on Mechanical Properties of the Mixed Bainite-martensite Microstructure in D6AC Steel. J. Mater. Sci. Technol. 2012, 28, 336-342. [CrossRef]

48. Bhadeshia, H.K.D.H. Bainite in Steels: Transformations, Microstructure and Properties; IOM Communications Ltd.: London, UK, 2001; Available online: https://books.google.co.id/books?id=sF5RAAAAMAAJ (accessed on 1 August 2018).

49. Kunze, K.; Wright, S.I.; Adams, B.L.; Dingley, D.J. Advances in Automatic EBSP Single Orientation Measurements. Textures Microstruct. 1993, 20, 41-54. [CrossRef]

50. Wilson, A.; Madison, J.; Spanos, G. Determining phase volume fraction in steels by electron backscattered diffraction. Scr. Mater. 2001, 45, 1335-1340. [CrossRef]

51. Wu, J.; Wray, P.J.; Garcia, C.I.; Hua, M.; DeArdo, A.J. Image Quality Analysis: A New Method of Characterizing Microstructures. ISIJ Int. 2005, 45, 254-262. [CrossRef]

52. García-Mateo, C.; Caballero, F.G. The Role of Retained Austenite on Tensile Properties of Steels with Bainitic Microstructures. Mater. Trans. 2005, 46, 1839-1846. [CrossRef]

53. Kumar, A.; Makineni, S.; Dutta, A.; Goulas, C.; Steenbergen, M.; Petrov, R.; Sietsma, J. Design of high-strength and damage-resistant carbide-free fine bainitic steels for railway crossing applications. Mater. Sci. Eng. A 2019, 759, 210-223. [CrossRef]

54. Podder, A.S.; Lonardelli, I.; Molinari, A.; Bhadeshia, H.K.D.H. Thermal stability of retained austenite in bainitic steel: an in situ study. Proc. R. Soc. A: Math. Phys. Eng. Sci. 2011, 467, 3141-3156. [CrossRef]

55. Kumar, A.; Dutta, A.; Makineni, S.; Herbig, M.; Petrov, R.; Sietsma, J.; Makeneni, S. In-situ observation of strain partitioning and damage development in continuously cooled carbide-free bainitic steels using micro digital image correlation. Mater. Sci. Eng. A 2019, 757, 107-116. [CrossRef]

56. Hajizad, O.; Kumar, A.; Li, Z.; Petrov, R.H.; Sietsma, J.; Dollevoet, R. Micromechanical modelling of strain partitioning and damage initiation in a continuously cooled carbide free bainitic steel and validation using in-situ tensile experiment. Unpublished work. 2019.

57. Hajizad, O.; Kumar, A.; Li, Z.; Petrov, R.H.; Sietsma, J.; Dollevoet, R. Crystal plasticity modelling of strain partitioning in high strength carbide free bainitic steel and validation using in-situ tensile experiments. Unpublished work. 2019.

58. Skobir, D.A.; Vodopivec, F.; Kosec, L.; Jenko, M.; Vojvodič-Tuma, J.; Vojvodič-Tuma, J. Influence of Precipitates Size and Distribution on Room Temperature Mechanical Properties and Accelerated Creep of X20CrMoV121. Steel Res. Int. 2004, 75, 196-203. [CrossRef]

59. Bracke, L.; Xu, W. Effect of the Cr Content and Coiling Temperature on the Properties of Hot Rolled High Strength Lower Bainitic Steel. ISIJ Int. 2015, 55, 2206-2211. [CrossRef]

60. Tian, J.; Xu, G.; Zhou, M.; Hu, H.; Wan, X. The Effects of Cr and Al Addition on Transformation and Properties in Low-Carbon Bainitic Steels. Metals 2017, 7, 40. [CrossRef]

61. Zhou, M.; Xu, G.; Tian, J.; Hu, H.; Yuan, Q. Bainitic Transformation and Properties of Low Carbon Carbide-Free Bainitic Steels with Cr Addition. Metals 2017, 7, 263. [CrossRef]

(C) 2019 by the authors. Licensee MDPI, Basel, Switzerland. This article is an open access article distributed under the terms and conditions of the Creative Commons Attribution (CC BY) license (http://creativecommons.org/licenses/by/4.0/). 